\title{
KARYOLOGICAL STUDY IN BACKCROSS HYBRIDS BETWEEN THE STERLET, ACIPENSER RUTHENUS, AND KALUGA, A. DAURICUS (ACTINOPTERYGII: ACIPENSERIFORMES: ACIPENSERIDAE): A. RUTHENUS $\times($ A. RUTHENUS $\times$ A. DAURICUS) AND A. DAURICUS $\times($ A. RUTHENUS $\times$ A. DAURICUS $)$
}

\author{
Victor P. VASIL'EV ${ }^{1}$, Eugene I. RACHEK ${ }^{2}$, Elena B. LEBEDEVA ${ }^{1}$, \\ and Ekaterina D. VASIL'EVA ${ }^{3 *}$ \\ ${ }^{1}$ Severtsov Institute of Ecology and Evolution, Russian Academy of Sciences, Moscow, Russia \\ ${ }^{2}$ Pacific Scientific Research Fisheries Centre (TINRO Centre), Vladivostok, Russia \\ ${ }^{3}$ Zoological Museum, Moscow State University, Moscow, Russia
}

Vasil'ev V.P., Rachek E.I., Lebedeva E.B., Vasil'eva E.D. 2014. Karyological study in backcross hybrids between the sterlet, Acipenser ruthenus, and kaluga, A. dauricus (Actinopterygii: Acipenseriformes: Acipenseridae): A. ruthenus $\times($ A. ruthenus $\times$ A. dauricus $)$ and A. dauricus $\times($ A. ruthenus $\times$ A. dauricus $)$. Acta Ichthyol. Piscat. 44 (4): 301-308.

Background. Acipenserid fishes may be divided into three groups in terms of their ploidy levels: 1) 120-chromosomes, 2) 250-270-chromosomes, and 3) about 370-chromosomes. The experimental crosses show that sturgeon species with the same ploidy often produce fertile hybrids, whereas the hybrids between species with different ploidy cannot reproduce because of female sterility or full sterility. To date, the only case of backcross hybrids obtained by hybridization of sturgeons with different ploidy is known: in these crosses, the sterlet, Acipenser ruthenus Linnaeus, 1758, with about 120 chromosomes and kaluga, Acipenser dauricus Georgi, 1775, with about 270 chromosomes were used as parental species; numerous progenies were obtained for females of both species and fertile hybrid males. The aims of this study were to determine the chromosome numbers in hybrid spermatozoa, involved in the production of viable backcross progenies, and to ascertain the chromosome numbers in backcrosses.

Materials and methods. The experiments for obtaining backcrosses were conducted in the Luchegorsk experimental station of the TINRO Centre in 2010. 16 one-year-old backcross hybrids sterlet $\times$ (sterlet $\times$ kaluga) and 14 one-year-old backcrosses kaluga $\times$ (sterlet $\times$ kaluga) were karyologically studied by using previously described method. From one to 23 metaphase plates were analyzed from every studied fish.

Results. Average chromosome numbers in 14 backcross hybrids sterlet $\times$ (sterlet $\times$ kaluga) varied from 139 to 157. It means that hybrid males (sterlet $\times$ kaluga), participated in their origin, produced spermatozoa with $79-87$ chromosomes. Two other backcrosses sterlet $\times$ (sterlet $\times$ kaluga) had about 178 and 184 chromosomes. Thus, they got 118-124 chromosomes from their fathers. Among backcrosses kaluga $\times($ sterlet $\times$ kaluga), 11 specimens had 201-214 chromosomes, and three specimens: 219-223. It means that hybrid males, participating in their origin, should produce spermatozoa with 66-84 and 84-93 chromosomes, respectively.

Conclusion. This study suggests non-random generation of chromosome sets in spermatozoa of fertile sterlet $\times$ kaluga hybrids. However, the mechanisms of meiosis, providing a non-random production of spermatozoa with similar numbers of chromosomes, are still unknown.

Keywords: fertility, karyotypes, mechanisms of meiosis, ploidy levels, sturgeon hybrids

\section{INTRODUCTION}

Many species of sturgeons have a high ability to form viable and more or less fertile hybrids by artificial crosses (Nikolûkin 1972); the interbreeding between various combinations of sturgeon species was also observed in nature or assumed from some morphological and genetic data (Soldatov 1915, Berg 1948, Vasil'ev 1979, Birstein et al. 1997, Ene and Suciu 2001, Ludwig et al. 2002, 2009). The property of easy interspecific hybridization is widely used to produce sturgeon hybrid stocks with economically

\footnotetext{
* Correspondence: Dr. Ekaterina D. Vasil'еva (Екатерина Васильева), Зоологический музей, Московский государственный университет, Большая Никитская 6 , Moskva, 125009 Russia, phone: +7 495 6294906, fax: +7 495 6294825, e-mail: (EDV) vas_katerina@mail.ru, (VPV) vas_katerina@mail.ru, (EIR) rachek@tinro.ru, (EBL)lebedester@gmail.com.
} 
valuable traits. The most valuable hybrids are crosses between the great sturgeon, Acipenser huso Linnaeus, 1758, and the sterlet, Acipenser ruthenus Linnaeus, 1758 (so called Russian hybrid or bester), as well as the hybrids between kaluga, Acipenser dauricus Georgi, 1775, and the Amur sturgeon, Acipenser schrenckii Brandt, 1869. The recent taxonomic revision by using recent molecular genetic, karyological, and morphological evidences (Vasil'eva et al. 2009) proved that Huso Brandt et Ratzeburg, 1833 is not valid genus, but a junior synonym of Acipenser Linnaeus, 1758. Thus the great sturgeon and kaluga were returned to Acipenser as they have originally been described (see Parin et al. 2014). The last kind of hybrids, called Chinese hybrid, is an important object of sturgeon aquaculture in China, as well as in some fish farms in the Far East of Russia (Li et al. 2009, Rachek et al. 2010). The search for other commercially valuable hybrids is still ongoing nowadays (Svirskij and Raček 2001, Poduška and Armâninov 2006, Raček et al. 2010, Poduška 2011).

The very first karyological study of sturgeons (Serebrâkova 1969) revealed that the results of interspecific hybridization in these fishes depend on the chromosome numbers of parental species. To date, almost all sturgeon species have been karyotyped (except Acipenser dabryanus Duméril, 1869). As a result, three ploidy levels were disclosed in these fishes:

- Species with about 120 chromosomes;

-250-270-chromosome species; and

- One species with about 370 chromosomes (see Fontana et al. 2008, Vasil'ev 2009).

Withal, large numbers of artificial hybrids between different sturgeon species have been obtained or were trying to obtain till now. These studies resulted in the following main conclusions:

Sturgeon species with the same ploidy level often produce normal fertile hybrid progenies which are able for successful reproduction (for instance, bester and Chinese hybrid).

The interbreeding of sturgeon species with different ploidy levels results in fully sterile or sub-fertile progeny.

For example, fully sterile progeny was obtained by hybridization between the great sturgeon with $\sim 120$ chromosomes and the Russian sturgeon, Acipenser gueldenstaedtii Brandt et Ratzeburg, 1833, with 250 chromosomes (Nikolûkin 1972). High probability of complete sterility of reciprocal hybrids between these species was also concluded by Arefjev and Nikolaev (1991) due to revealed imbalance of non-intermediate hybrid karyotypes, but further karyological studies (Gorshkova et al. 1996) demonstrated that these hybrids have chromosome number intermediate to those of parental species. However, in the case of female sterility, hybrid males can be sub-fertile; this was proved for the reciprocal hybrids between the Russian sturgeon and 120-chromosome sterlet (Burcev 1962) as well as the hybrids between the sterlet and the Siberian sturgeon, Acipenser baerii Brandt, 1869, with 250 chromosomes (Poduška 2004). Probably, males of the reciprocal hybrids between the Russian sturgeon and the starry sturgeon, Acipenser stellatus Pallas, 1771, with $\sim 120$ chromosomes are also sub-fertile (hybrid females are sterile) (Burcev 1967, Nikolûkin 1972).

The observed sub-fertility of sturgeon hybrids between species with different ploidy levels corresponds to the Haldane's rule, which is manifested in more than $80 \%$ of vertebrate hybrids: only one sex, namely homogametic, is fully fertile, whereas heterogametic sex is sterile (Haldane 1922, Turelli 1998). To date, the evidences of female heterogamety were reported for bester and several sturgeon species: Acipenser transmontanus Richardson, 1937, Acipenser brevirostrum Lesueur, 1818, A. stellatus, and $A$. baerii (see Van Eenennaam et al. 1999b, Omoto et al. 2005, Flynn et al. 2006, Badrtdinov et al. 2008, FoppBayat 2010). Additionally, differences in karyotypes are known to play a certain role in the maintaining of isolation mechanisms in fishes. It was demonstrated earlier that the realization of interspecific hybridization in nature, as well as its probability in different fish groups (sturgeons, salmonids, labrids), correlates with the differences in karyotypes (Vasil'ev 1979, 1985). For example, in the Volga River basin, sturgeon species with different karyotypes occur in the same spawning grounds much more often than species with similar karyotypes; whereas species with similar karyotypes are usually separated in space and / or time during their spawning. Thus, under natural conditions within limits of the native area, the probability of hybridization between sturgeon species with different ploidy levels is generally higher than between the species with the same chromosome numbers (Vasil'ev 1979). It should be mentioned, that some authors believe that "in general, natural interspecific hybridization happens more frequently between closely related fish species" because of "genetic incompatibility of parental genomes" of "taxonomically distant vertebrate species" (Havelka et al. 2011, p. 97). But certainly, these authors confuse hybridization events and their results. Whereas the frequencies of hybridization events between closely related or distant species are explained by balance of pre-copulatory and post-copulatory isolating mechanisms in the contact zones (Vasil'ev 1979, 2009).

To date, the only case of backcross hybrids obtained by hybridization of sturgeon species with different ploidy levels is known. In these experiments, the sterlet, Acipenser ruthenus, and kaluga, A. dauricus, were used as parental species (Raček et al. 2010). As it was mentioned, the sterlet has about 120 chromosomes (Fontana et al. 1975, Vasil'ev, 1985, Ráb 1986), and it was used as one of parental species of bester, the most valuable hybrid in sturgeon aquaculture. The second parental species of bester was the great sturgeon, A. huso, which also has about 120 chromosomes (Birstein and Vasiliev 1987). For many years and even today, the great sturgeon and kaluga was accepted as closely related species taxonomically separated from other Acipenser species as a distinct genus Huso Brandt et Ratzeburg, 1833 or even subfamily Husinae (see Berg 1948, Findeis 1997, Nelson 2006, 
Froese and Pauly 2014). Respectively, it was accepted that $A$. dauricus also belongs to 120 -chromosome sturgeon group (Birstein et al. 1993, 1997). Moreover, 120chromosome state of kaluga was especially "confirmed" by Ludwig et al. (2001) for the broodstock from the Luchegorsk experimental station of the Pacific Scientific Research Fisheries Centre (TINRO Centre). Therefore, A. dauricus was assumed as a suitable parental species for development of a new hybrid broodstock for sturgeon aquaculture, "kaster", by hybridization with $A$. ruthenus. In 2005, a numerous hybrid progeny $A$. ruthenus $\times A$. dauricus was produced at first in the Luchegorsk experimental station (Raček and Svirskij 2010). In 2009, the analysis of gonads in these males revealed that they possessed different degrees of fertility with some fully sterile specimens (Raček et al. 2010). Next year, viable backcrosses sterlet $\times($ sterlet $\times$ kaluga $)$ and kaluga $\times($ sterlet $\times$ kaluga $)$ were produced in mass amounts by using hybrid sperm. However, the special karyological studies proved that kaluga has about 270 chromosomes (Vasil'ev et al. 2009, 2010). Therefore, the hybrid sterlet $\times$ kaluga should be sterile or sub-fertile on the basis of previous findings of hybridization between species with different ploidy levels. In this connection, the appearance of numerous backcrosses causes two questions:

- How many chromosomes in hybrid spermatozoa involved in fertilization to produce viable backcross progenies; and

- How many chromosomes have backcross hybrids?

The main goal of this research was to find answers on these questions.

Beyond this goal, remains another important problem, namely, the behaviour of chromosomes in meiosis of hybrid males. This information can be obtained in the study of metaphases of the first meiotic division and / or the synaptonemal complex analysis in spermatocytes of hybrid males (see Bogdanov and Kolomiec 2007). To date, the synaptonemal complex was studied in the only sturgeon species, Acipenser transmontanus Richardson, 1837 (see Van Eenennaam et al. 1998, 1999a). The study showed no evidence of multivalent formation in meiosis, but it was to be expected, since $A$. transmontanus belongs to tetraploid species with about 280 chromosomes (Van Eenennaam et al. 1999a). In addition, the authors observed 0-3 univalents and 1-7 self-paired foldback elements with no obvious centromeric region that, according to the authors, may represent accessory chromosomes. Because of tetraploid state of $A$. dauricus, not more than 60 bivalents formation should be expected in meiosis of hybrid males $A$. ruthenus $\times A$. dauricus, in case of the presence of 60 chromosomes homeological to chromosomes in the haploid set of $A$. dauricus $(n=135)$ among 60 chromosomes in haploid set of $A$. ruthenus. Respectively, about 75 meiotic chromosomes will be univalents. However, in any case, this information cannot answer the questions that are the purpose of the present study. But only direct determination of chromosome numbers in backcross hybrids allows to accurately determine the number of chromosomes in hybrid sperm capable for reproduction.

\section{MATERIALS AND METHODS}

Parental fishes - sterlet, Acipenser ruthenus, and kaluga, A. dauricus - originated from the Luchegorsk experimental station of the TINRO Centre. To produce backcrosses Acipenser ruthenus $\times($ A. ruthenus $\times$ A. dauricus $)$ one female of the sterlet, which belong to the broodstock obtained from the Volga River population, was used. In May 2010, eggs from this female were inseminated with the mixture of sperm from three five-years-old hybrid males sterlet $\times$ kaluga. The seminal fluid from every hybrid male was almost transparent, with spermatozoa concentration about 57000 per $1 \mathrm{~mL}$. The yield of larvae was $48.5 \%$. To obtain backcrosses kaluga $\times$ (sterlet $\times$ kaluga) the mixture of eggs from three kaluga specimens and the mixture of sperm from three five-years-old hybrid males sterlet $\times$ kaluga were used. The seminal fluid from one hybrid male had milk colour with spermatozoa concentration about 4900000 per $1 \mathrm{~mL}$; the seminal fluid from the second male had colour of diluted milk with spermatozoa concentration about 56000 per $1 \mathrm{~mL}$; and the seminal fluid from the third male was turbid. The yield of larvae was $24.8 \%$ (Raček et al. 2010).

In 2011, for karyological study, 16 one-year-old backcrosses sterlet $\times($ sterlet $\times$ kaluga $)$ with total body length 228-366 (on average 313) $\mathrm{mm}$ and 14 one-year-old backcrosses kaluga $\times($ sterlet $\times$ kaluga $)$ with total body length 257-434 (on average 305) $\mathrm{mm}$ were used. (Parental hybrid males sterlet $\times$ kaluga and females of pure species were not karyotyped.) All specimens were injected with $1-3 \mathrm{~mL}$ colchicine solution $(0.5 \%-0.6 \%)$ depending on their weight. After $4.5-10.5 \mathrm{~h}$ cells of the head lymphoid organ were used for chromosome slide preparing by using previously published karyological method (Vasil'ev and Sokolov 1980). The study was conducted by using anesthesia of fishes with a solution of MS-222. Metaphase chromosomes stained in 4\% Giemsa solution in phosphate buffer ( $\mathrm{pH}$ 6.8) were counted with PC software Quick Photo Micro. For karyological study we selected metaphase plates in which the chromosome number can be count accurate to 6-10 chromosomes. From one to 23 metaphase plates were analyzed from every studied fish (Table 1).

\section{RESULTS}

In backcross hybrids Acipenser ruthenus $\times($ A. ruthenus $\times A$. dauricus) average chromosome numbers varied from 139 to 184 (Table 1). The majority of specimens (14) had average values varying from 139 to 157 (Fig. 1). This range of variation approximately corresponds to an accuracy of chromosomes calculations. The appearance of backcross hybrids with such chromosome numbers indicates that parental hybrid males (A. ruthenus $\times$ A. dauricus), used in experimental crosses, produced spermatozoa with chromosome numbers from 79 to 97 . These values were calculated by a deduction of haploid chromosome set (60 chromo- 
somes) of maternal species, A. ruthenus, from 139-157 chromosome set in backcross hybrids. Only two backcross hybrids sterlet $\times$ (sterlet $\times$ kaluga) differed from the others: they had average values of chromosome numbers 178 and 184 (Table 1). The individuals with these karyotypes could appear if parental hybrid males have produced spermatozoa with 118-124 chromosomes.

Backcross hybrids $A$. dauricus $\times($ A .ruthenus $\times A$. dauricus) also were represented by two groups with different average chromosome numbers. 11 specimens had average chromosome numbers varied from 201 to 214 (Table 1). Since haploid set of maternal species, A. dauricus, includes 130-135 chromosomes, paternal hybrid males of these backcrosses should produce spermatozoa with 66-84 chromosomes. The other three backcrosses possessed average chromosome numbers from 219 to 223 (Table 1, Fig. 2). It means that their hybrid fathers should produce spermatozoa with 84-93 chromosomes.

\section{DISCUSSION}

The hybrid form Acipenser ruthenus $\times$ A. dauricus was at first obtained in the Luchegorsk experimental station of the TINRO Centre in 2005 for development of broodstocks in sturgeon aquaculture, as presumed analogue of bester. But following karyological studies on A. dauricus revealed this species as a member of 250-270chromosome sturgeon group (Vasil'ev et al. 2009, 2010). Thus, its ploidy level differs from ploidy level of A. ruthenus with about 120 chromosomes. This means that

Table 1

Karyological characterization of individual backcross hybrids between Acipenser ruthenus (AR) and A. dauricus (AD)

\begin{tabular}{|c|c|c|c|c|c|}
\hline \multicolumn{6}{|c|}{ Backcross hybrids } \\
\hline \multicolumn{3}{|c|}{$\mathrm{AR} \times(\mathrm{AR} \times \mathrm{AD})$} & \multicolumn{3}{|c|}{$\mathrm{AD} \times(\mathrm{AR} \times \mathrm{AD})$} \\
\hline No. & $2 n$ & $m$ & No. & $2 n$ & $m$ \\
\hline 1 & 143 & 8 & 1 & 208 & 4 \\
\hline 2 & 150 & 3 & 2 & 205 & 2 \\
\hline 3 & 140 & 5 & 3 & 205 & 4 \\
\hline 4 & 141 & 6 & 4 & 201 & 2 \\
\hline 5 & 143 & 20 & 5 & 207 & 15 \\
\hline 6 & 142 & 10 & 6 & 207 & 23 \\
\hline 7 & 146 & 6 & 7 & 214 & 16 \\
\hline 8 & 139 & 2 & 8 & 213 & 10 \\
\hline 9 & 145 & 1 & 9 & 202 & 1 \\
\hline 10 & 178 & 2 & 10 & 221 & 3 \\
\hline 11 & 184 & 1 & 11 & 202 & 1 \\
\hline 12 & 148 & 9 & 12 & 213 & 2 \\
\hline 13 & 147 & 17 & 13 & 219 & 4 \\
\hline 14 & 147 & 2 & 14 & 223 & 9 \\
\hline 15 & 157 & 2 & & & \\
\hline 16 & 146 & 1 & & & \\
\hline
\end{tabular}

No. $=$ an individual number of specimen, $2 \mathrm{n}=$ average diploid chromosome number, $m=$ numbers of studied metaphases. the hybrid form $A$. ruthenus $\times$ A. dauricus cannot be expected as a valuable fish for aquaculture (as the bester is), because of its presumed sterility or sub-fertility, generally observed in hybrids between sturgeons with different ploidy levels. However, hybrid males A. ruthenus $\times$ $A$. dauricus demonstrated enough high fertility and produced numerous progenies by backcrosses with females from pure species, A. ruthenus and $A$. dauricus. To explain this high fertility of hybrid males, three hypotheses were proposed before karyological study of backcross hybrids.

The first hypothesis involves premeiotic endoreduplication of chromosomes. In this case, hybrid males produce unreduced diploid spermatozoa: haploid chromosome set from Acipenser ruthenus (about 60 chromosomes) plus haploid chromosome set from A. dauricus (about 130-135 chromosomes), i.e., in total, about 190-195 chromosomes. As a result, backcross hybrids should be triploids with about 255 chromosomes in sterlet $\times$ (sterlet $\times$ kaluga) crosses and with about 330 chromosomes in kaluga $\times$ (sterlet $\times$ kaluga). For today, the artificial interspecific hybrids producing unreduced eggs are well known in different groups of fishes (Salmonidae, Cyprinidae, Cyprinodontidae, Orysiatidae, Centrarchidae) (Ojima et al. 1975, Čerfas et al. 1981, Dawley et al. 1985, Dawley 1987, 1992, Sakaizumi et al. 1993, Kurita et al. 1995, Dannewitz and Jannson 1996). Unreduced diploid spermatozoa was recorded for the hybrids between species of genus Misgurnus (Cobitidae), but these spermatozoa possessed low motility and were unable to fertilize eggs for developing viable larva (Fujimoto et al. 2008). However, the appearance of fertile unreduced spermatozoa may be probable for hybrids of species with female heterogamety.

The second hypothesis assumes hybridogenesis which is well known in some semi-clonal fish and amphibians (see Schultz 1969, Vrijenhoek 1972). When hybridogenesis, hybrids produce spermatozoa with maternal haploid set only; paternal genome is selectively eliminated. According to this hypothesis, backcross hybrids sterlet $x$ (sterlet $\times$ kaluga) should have about 120 chromosomes, whereas backcross hybrids kaluga $\times(\text { sterlet } \times \text { kaluga })_{-}$ about 195 chromosomes.

The third hypothesis presumes that hybrids produce spermatozoa with different chromosome numbers, and the range of variability should be enough wide because parental species have significantly different genomes (about 120 and about 270 chromosomes). One of the reasons of chromosome variability in spermatozoa may be karyological heterogeneity within hybrid Acipenser ruthenus $\times$ A. dauricus males. As it was mentioned above, Arefjev and Nikolaev (1991) found variable, non-intermediate chromosome numbers in reciprocal hybrids between $A$. huso and A. gueldenstaedtii, species with different ploidy levels. Other sources of chromosome variability in spermatozoa can be caused by the mechanisms of spermatogenesis in hybrids: chromosome abnormalities often occur in hybrid cells of various organisms including fishes (Fujiwara et al. 1997, Iwamatsu et al. 2003, Sakai et al. 2007). In any case, a high proportion of genetically 


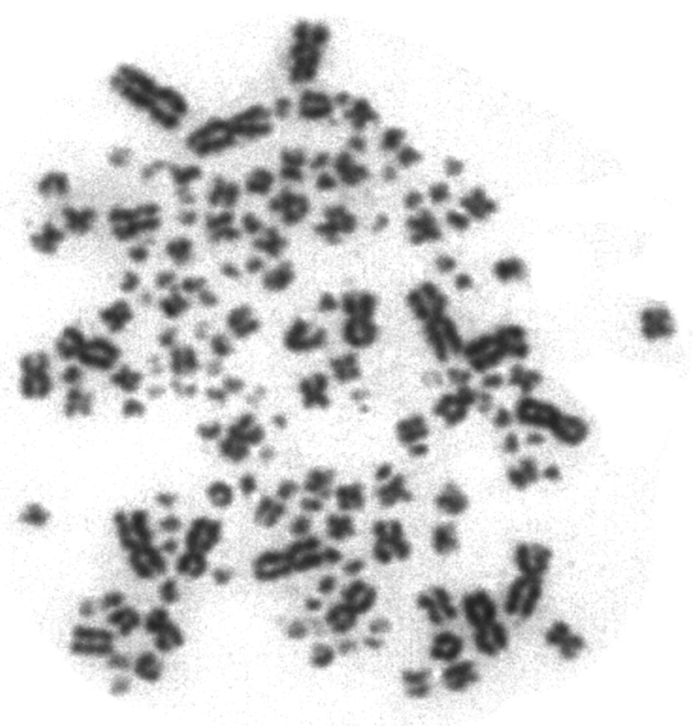

Fig. 1. Metaphase plate of backcross hybrid Acipenser ruthenus $\times($ A. ruthenus $\times$ A. dauricus $)$; chromosome number $(2 \mathrm{n})=152 \pm 2$

unbalanced spermatozoa can be expected, as well as the low yield value of viable backcross hybrids.

The karyotypes obtained in this study for backcross hybrids do not agree with the first hypothesis about unreduced diploid spermatozoa producing by hybrid males. The second hypothesis seems more probable, but our results on chromosome numbers in backcrosses suppose that, along with maternal haploid set (from Acipenser ruthenus), spermatozoa of hybrids get about 15-25 'extra' chromosomes (probably microchromosomes) from the paternal haploid set (A. dauricus).

The third hypothesis is highly improbable. In fact, the observed variation of chromosome numbers in most Acipenser ruthenus $\times(A$. ruthenus $\times A$. dauricus $)$ and A. dauricus $\times(A$. ruthenus $\times A$. dauricus $)$ backcross hybrids is not large, and moreover, it is approximately within an accuracy of chromosome counting. This means that most spermatozoa suitable for producing viable backcross hybrids have similar chromosome numbers. Certainly, one can assume that spermatozoa have significantly variable chromosome number, but only a few of appearing backcross hybrids do survive, namely, A. ruthenus $\times($ A. ruthenus $\times$ A. dauricus $)$ with 139-157 and 178-184 chromosomes, and $A$. dauricus $\times$ (A. ruthenus $\times$ A. dauricus) with 201-214 and 219-223 chromosomes. However, this is unlikely, because the survival of $A$. ruthenus $\times(A$. ruthenus $\times A$. dauricus $)$ individuals was quite high, reaching 48.5\% (Raček et al. 2010). Accordingly, taking into account a natural mortality of embryos, the proportion of spermatozoa with 79-97 and 118-124 chromosomes should exceed 50\%. The survival of $A$. dauricus $\times(A$. ruthenus $\times A$. dauricus $)$ backcross hybrids was lower, but also enough large (24.8\%) (Raček et al. 2010). These data indicates that, despite large differences between parental karyotypes, the generation of

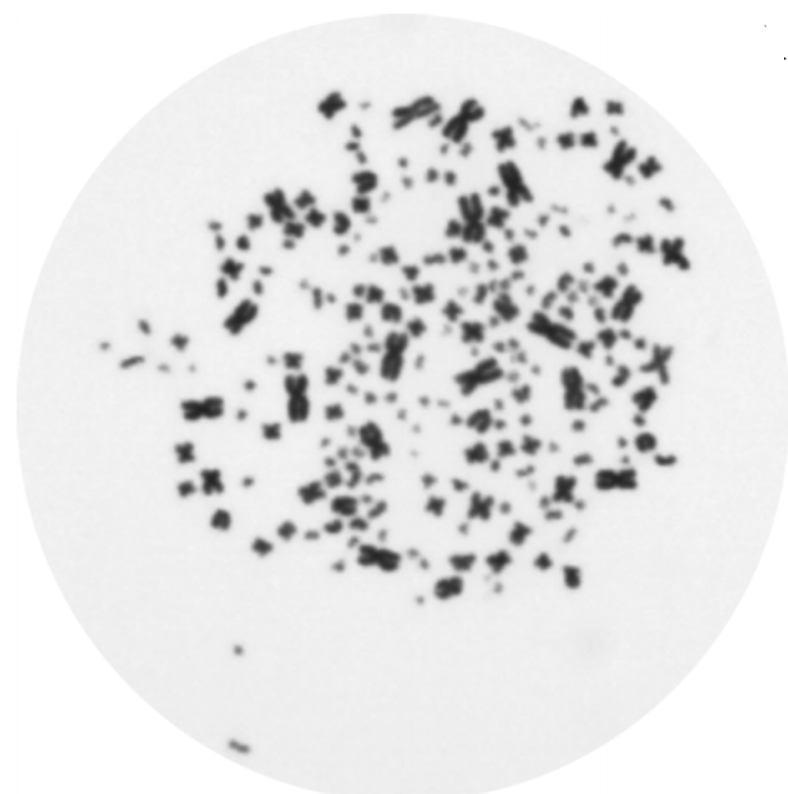

Fig. 2. Metaphase plate of backcross hybrid Acipenser dauricus $\times($ A. ruthenus $\times A$. dauricus $)$; chromosome number $(2 \mathrm{n})=224 \pm 4$

chromosome sets of spermatozoa by $A$. ruthenus $\times A$. dauricus hybrids is not accidental. Moreover, the individual hybrid males can differ in their ability to produce capable of fertilization spermatozoa with certain chromosome number. This assumption follows from the differences observed in the results of crossings between hybrid males and females from different parental species.

The mechanisms of meiosis, providing a non-random production of sperm with similar numbers of chromosomes, are unknown. The probability to reveal them by study of meiotic chromosomes or by synaptonemal complex analysis (Van Eenennaam et al. 1998) in hybrid males with about 195 chromosomes seems questionable, but it may be a goal of a special study. However, one can assume that the specific chromosome sets, discovered in spermatozoa of hybrids between $A$. ruthenus and A. dauricus, could be related with evolutional origins of their parental species. Indeed, A. dauricus belongs to multi-chromosome tetraploid species and its karyotype could originate by summation of different low-chromosome diploid karyotypes in conformity with hypothesized allopolyploid evolution in sturgeons (Vasil'ev 1999, 2009). The low-chromosome diploid karyotype of $A$. ruthenus can be closely related to at least one of parental karyotypes of this "evolutionary hybrid". Therefore, it should be expected that chromosomes in the karyotype of $A$. ruthenus are more or less homologous to parts of chromosomes in the karyotype of $A$. dauricus.

In any event, regardless of the hypotheses proposed and discussed here, the present study demonstrates that fertile hybrid $A$. ruthenus $\times A$. dauricus males produce spermatozoa with certain chromosome numbers. This suggests that their fertility is related with non-random generation of chromosome sets in sperm. 


\section{ACKNOWLEDGEMENTS}

The authors are grateful to Viktor G. Svirskii-a famous specialist on sturgeon aquaculture-for his encouragement and friendly attitude for the presently reported study, and to Dmitrij Yu. Amvrosov, as well as all employees of the Luchegorsk experimental station of TINRO Centre for their help in the provision of this study and growing of specimens which were used for karyological investigations. This study was partially supported by the Russian Foundation for Basic Researches, project no. 12-04-01012-a and the Federal Target Program, agreement No. 14.604.21.0129, a unique ID for Applied Scientific Research RFMEFI60414X0129.

\section{REFERENCES}

Arefjev V.A., Nikolaev A.I. 1991. Cytological analysis of the reciprocal hybrids between low- and high-chromosome acipenserids, the great sturgeon, Huso huso (L.), and the Russian sturgeon, Acipenser gueldenstaedtii Brandt. Cytologia 56 (4): 495-502.

Badrtdinov O.A., Kovalev K.V., Lebedeva E.B., Vasil'eva E.D., Recoubratsky A.V., Grunina A.S., Chebanov M.S., Vasil'ev V.P. 2008. Entirely male gynogenetic offspring of Acipenser stellatus (Pisces, Acipenseridae). Doklady Biological Sciences 423 (1): 392-394. DOI: 10.1134/ S0012496608060070

Berg L.S. 1948. Ryby presnyh vod SSSR i sopredel'nyh stran. [Fishes of fresh waters of the USSR and adjacent countries.] Part 1. Izdatel'stvo Akademii Nauk SSSR, Moskva-Leningrad. [In Russian.]

Birstein V.J., Hanner R., DeSalle R. 1997. Phylogeny of the Acipenseriformes: Cytogenetic and molecular approaches. Environmental Biology of Fishes 48 (1-4): 127-155. DOI: 10.1023/A:1007366100353

Birstein V.J., Poletaev A.I., Goncharov B.F. 1993. DNA content in Eurasian sturgeon species determined by flow cytometry. Cytometry Part A 14 (4): 377-383. DOI: 10.1002/cyto.990140406

Birstein V.J., Vasiliev V.P. 1987. Tetraploid-octoploid relationships and karyological evolution in the order Acipenseriformes (Pisces): Karyotypes, nucleoli, and nucleolus-organizer regions in four acipenserid species. Genetica 73 (1): 3-12. DOI: 10.1007/BF00126973

Bogdanov Û.F. [Bogdanov Yu.F.], Kolomiec O.L. [Kolomiets O.L.] 2007. Sinaptonemnyj kompleks - indikator dinamiki mejoza i izmienčivosti hromosom. [Synaptonemal complex - indicator of the dynamics of meiosis and chromosome variation.] KMK Scientific Press, Moscow. [In Russian with English summary.]

Burcev I.A. [Burtsev I.A.] 1962. O vosproizvoditel'noj sposobnosti gibrida osetra so sterlâd'û. [On the reproductive capacity of hybrid between the sturgeon and the sterlet sturgeon.] Doklady AN SSSR 144 (6): 1377-1379. [In Russian.]

Burcev I.A. [Burtsev I.A.] 1967. O vliânii pitaniâ na gametogenez nekotoryh gibridov osetrovyh ryb pri prudovom vyrašivanii. [The effect of food on gametogenesis in some sturgeon hybrids cultivating in ponds.] Pp. 241-243. In: Karzinkin G.S. (ed.) Obmen vešestv i biohimiâ ryb. Nauka, Moskva. [In Russian.]
Čerfas N.B. [Cherfas N.B.], Gomel'skij B.I. [Gomelskyi B.I.], Emel'ânova O.V. [Emelyanova O.V.], Rekubratskij A.B. [Rekubratskyi A.B.] 1981. Triploidiâ u vozvratnyh gibridov serebrânogo karasâ s karpom. [Triploidy in back-cross hybrids between crucian carp and common carp.] Genetica 17 (6): 1136-1139. [In Russian.]

Dannewitz J., Jannson H. 1996. Triploid progeny from a female Atlantic salmon $\times$ brown trout hybrid backcrossed to a male brown trout. Journal of Fish Biology 48 (1): 144-146. DOI: 10.1111/j.1095-8649.1996.tb01425.x

Dawley R.M. 1987. Hybridization and polyploidy in a community of three sunfish species (Pisces: Centrarchidae). Copeia 1987 (2): 326-335. DOI: $10.2307 / 1445768$

Dawley R.M. 1992. Clonal hybrids of the common laboratory fish Fundulus heteroclitus. Proceedings of the National Academy of Sciences of the United States of America 89 (6): 2485-2488.

Dawley R.M., Graham J.H., Schultz R.J. 1985. Triploid progeny of pumpkinseed $\times$ green sunfish hybrids. Journal of Heredity 76 (4): 251-257.

Ene A.C., Suciu R. 2001. Karyological investigation in natural hybrids of sturgeons of the lower Danube River. Pp. 34. In: Programme and Book of Abstracts. 10th European Congress of Ichthyology. ECI X "In the heart of Europe", September 3-7 2001, Prague, Czech Republic.

Findeis E.K. 1997. Osteology and phylogenetic interrelationships of sturgeons (Acipenseridae). Environmental Biology of Fishes 48 (1-4): 73-126. DOI: 10.1023/A:1007372832213

Flynn S.R., Matsuoka M., Reith M., Martin-Robichaud D.J., Benfey T.J. 2006. Gynogenesis and sex determination in shortnose sturgeon, Acipenser brevirostrum Lesuere. Aquaculture 253 (1-4): 721-727. DOI: 10.1016/j.aquaculture.2005.09.016

Fontana F., Congiu L., Mudrak V.A., Quattro J.M., Smith T.I.J., Ware K., Doroshov S.I. 2008. Evidence of hexaploid karyotype in shortnose sturgeon. Genome 51 (2): 113-119. DOI: 10.1139/g07-112

Fontana F., Janković D., Živković S. 1975. Somatic chromosomes of Acipenser ruthenus L. Arhiv bioloških nauka, Beograd 27 (1-2): 33-35.

Fopp-Bayat D. 2010. Meiotic gynogenesis revealed not homogametic female sex determination system in Siberian sturgeon (Acipenser baeri Brandt). Aquaculture 305 (1-4): 174-177. DOI: 10.1016/j.aquaculture.2010.04.011

Froese R., Pauly D. (eds.) 2014. FishBase. [version (06/2014)] www.fishbase.org

Fujimoto T., Yasui G.S., Yoshikawa H., Yamaha E., Arai K. 2008. Genetic and reproductive potential of spermatozoa of diploid and triploid males obtained from interspecific hybridization of Misgurnus anguillicaudatus female with M. mizolepis male. Journal of Applied Ichthyology 24 (4): 430-437. DOI: 10.1111/j.1439-0426.2008.01131.x

Fujiwara A., Abe S., Yamaha E., Yamazaki F., Yoshida M.C. 1997. Uniparental chromosome elimination in the early embryogenesis of the inviable salmonid hybrids between masu salmon female and rainbow trout male. Chromosoma 106 (1): 44-52.

Gorshkova G., Gorshkov S., Gordin H., Knibb W. 1996. Karyological studies in hybrids of beluga Huso huso (L.) and 
the Russian sturgeon Acipenser gueldenstaedti Brandt. Israeli Journal of Aquaculture/Bamidgeh 48 (Suppl. 1): 35-39.

Haldane J.B.S. 1922. Sex ratio and unisexual sterility in hybrid animals. Journal of Genetics 12 (2): 101-109. DOI: 10.1007/BF02983075

Havelka M., Kašpar V., Hulák M., Flajšhans M. 2011. Sturgeon genetics and cytogenetics: A review related to ploidy levels and interspecific hybridization. Folia Zoologica 60 (2): 93-103.

Iwamatsu T., Kobayashi H., Yamashita M., Shibata Y., Yusa A. 2003. Experimental hybridization among Oryzias species. II. Karyogamy and abnormality of chromosome separation in the cleavage of interspecific hybrids between Oryzias latipes and O. javanicus. Zoological Science 20 (11): 1381-1387. DOI: $10.2108 /$ zsj.20.1381

Kurita J., Oshiro T., Takashima F., Sakaizumi M. 1995. Cytogenetic studies on diploid and triploid oogenesis in interspecific hybrid fish between Oryzias latipes and O. curvinotus. Journal of Experimental Zoology 273 (3): 234-241. DOI: $10.1002 /$ jez.1402730308

Li B.R., Zou Y., Wei Q. 2009. Sturgeon aquaculture in China: Status and current difficulties as well as future strategies based on 2002-2006/2007 surveys in eleven provinces. Journal of Applied Ichthyology 25 (6): 632-639. DOI: 10.1111/j.1439-0426.2009.01366.x

Ludwig A., Belfiore N.M., Pitra C., Svirsky V., Jenneckens I. 2001. Genome duplication events and functional reduction of ploidy levels in sturgeon (Acipenser, Huso and Scaphirhynchus). Genetics 158 (3): 1203-1215.

Ludwig A., Debus L., Jenneckens I. 2002. A molecular approach to control the international trade in black caviar. International Review of Hydrobiology 87 (5-6): 661-674. DOI: $\quad 10.1002 / 1522-2632(200211) 87: 5 / 6<661:: A I D-$ IROH661>3.0.CO;2-S

Ludwig A., Lippold S., Debus L., Reinartz R. 2009. First evidence of hybridization between endangered sterlets (Acipenser ruthenus) and exotic Siberian sturgeons (Acipenser baerii) in the Danube River. Biological Invasions 11 (3): 753-760. DOI: 10.1007/s10530-008-9289-z

Nelson J.S. 2006. Fishes of the world. 4th edn. John Wiley and Sons, Hoboken, NJ, USA.

Nikolûkin N.I. [Nikolyukin N.I.] 1972. Otdalennaâ gibridizaciâ osetrovyh i kostistyh ryb (Teoriâ i praktika). [Distant hybridization in acipenserid and teleost fishes (Theory and practice).] Piŝevaâ promyšlennost', Moskva [In Russian].

Ojima Y., Hayashi M., Ueno K. 1975. Triploidy appeared in the back-cross offspring from funa carp crossing. Proceedings of the Japan Academy 51 (9): 702-706. DOI: 10.2183/pjab.1945.51.702

Omoto N., Maebayashi M., Adachi S., Arai K., Yamauchi K. 2005. Sex ratios of triploids and gynogenetic diploids induced in the hybrid sturgeon, the bester (Huso huso female $\times$ Acipenser ruthenus male). Aquaculture 245 (1-4): 39-47. DOI: 10.1016/j.aquaculture.2004.12.004

Parin N.V., Evseenko S.A., Vasil'eva E.D. 2014. Fishes of Russian seas: annotated catalogue. Archives of the Zoological Museum of Moscow Lomonosov State University. Vol. 53. KMK Scientific Press, Moscow.
Poduška S.B. [Podushka S.B.] 2004. Steril'ny li "steril'nye" gibridy osetrovyh? [Are "sterile" sturgeon hybrids sterile?] Pp. 202-203. In: Akvakul'tura osetrovyh ryb: dostiženiâ i perspektivy razvitiâ. III Meždunarodnaâ naučno-praktičeskaâ konferenciâ. Materialy dokladov. Al'fa-Ast, Astrahan', Russia. [In Russian.]

Poduška S.B. [Podushka S.B.] 2011. Ocenka različnyh vidov i gibridov osetrovyh kak ob'ektov tovarnogo vyraŝivaniâ. [The evaluation of different sturgeon species and hybrids as objects for commercial cultivation.] Pp. 90-91. In: Aktual'nye problemy obespečeniâ prodovol'stvennoj bezopasnosti ûga Rossii: innovacionnye tehnologii dlâ sohraneniâ bioresursov, plodorodiâ počv, melioracii i vodoobespečeniâ. Materialy meždunarodnoj naučnoj konferencii, 27-30 September 2011, Rostov-na-Donu, Russia). Izdatel'stvo JuNTs RAN, Rostovna-Donu, Russia. [In Russian.]

Poduška S.B. [Podushka S.B.], Armâninov I.V. [Armyaninov I.V.] 2006. Skreŝivanie lenskogo osetra s amurskimi osetrovymi v Karmanovskom rybhoze i rybovodnâ ocenka polučennyh gibridov. [The crossings between the Lena sturgeon and sturgeon from the Amur River in the Karmanovsky fish farm and the aquacultural evaluation of the obtained hybrids.] Pp. 160-161. In: Akvakul'tura osetrovyh ryb: dostiženiâ i perspektivy razvitiâ. Materialy dokladov IV Meždunarodnoj naučno-praktičeskoj konferencii. Izdatel'stvo VNIRO, Moskva. [In Russian.]

Ráb P. 1986. A note on the karyotype of the sterlet, Acipenser ruthenus (Pisces, Acipenseridae). Folia Zoologica 35 (1): 73-78.

Raček E.I. [Rachek E.I.], Svirskij V.G. [Svirskii V.G.] 2010. Industrial'noe rybovodstvo v TINRO-Centr (2000-2010 gg., ili 10 let spustâ). [Industrial fishery in TINRO Centre (2000-2010 years, or 10 years later).] Pp. 225-245. In: TINRO-85. Itogi desâtiletnej deâtel'nosti. 2000-2010 gg.: Sbornik statej. TINRO-Centr, Vladivostok, Russia. [In Russian.]

Rachek Y.I., Svirskii V.G., Skirin V.I. 2010. Generative and somatic production of female sturgeon at a research farm in Primorsky Krai as a basis for manufacturing gastronomic caviar. Russian Journal of Marine Biology 36 (7): 548-561. DOI: $10.1134 /$ S1063074010070084

Raček E.I. [Rachek E.I.], Svirskij V.G. [Svirskii V.G.], Skirin V.I., Lipin D.E. 2010. Éksperimental'noe podtverždenie fertil'nosti samcov mežrodovogo gibrida $\left(\mathrm{F}_{1}\right)$ sterlădi (Acipenser ruthenus) i kalugi (Huso dauricus). [The experimental confirmation of male fertility in intergeneral hybrid $\left(\mathrm{F}_{1}\right)$ between the sterlet sturgeon (Acipenser ruthenus) and kaluga (Huso dauricus).] Osetrovoe hozâjstvo 2010 (4): 52-60. [In Russian.]

Sakai C., Konno F., Nakano O., Iwai T., Yokota T., Lee J., Nishida-Umehara C., Kuroiwa A., Matsuda Y., Yamashita M. 2007. Chromosome elimination in the interspecific hybrid medaka between Oryzias latipes and $O$. hubbsi. Chromosome Research 15 (6): 697-709. DOI: 10.1007/s10577-007-1155-9

Sakaizumi M., Shimizu Y., Matsuzaki T., Hamaguchi S. 1993. Unreduced diploid eggs produced by interspecific hybrids between Oryzias latipes and O. curvinotus. Journal of Experimental Zoology 266 (4): 312-318. DOI: 10.1002/jez.1402660409 
Schultz R.J. 1969. Hybridization, unisexuality and polyploidy in the teleost Poeciliopsis (Poeciliidae) and other vertebrates. American Naturalist 103 (934): 605-619.

Serebrâkova E.V. [Serebryakova E.V.] 1969. Nekotorye dannye o hromosomnyh kompleksah osetrovyh ryb. [Some data on chromosomal complexes in sturgeon fishes.] Pp. 105-113. In: Genetika, selekciă i gibridizaciă ryb.] Nauka, Moskva. [In Russian.]

Soldatov V.K. 1915. Issledovanie osetrovyh Amura. [Studies of Acipenserids of Amur]. Materialy $\mathrm{k}$ poznaniû russkogo rybolovstva 3 (12): 95-415. [In Russian.]

Svirskij V.G. [Svirskii V.G.], Raček E.I. [Rachek E.I.] 2001. Gibridizaciâ kak élement resursosberegaûŝih tehnologij tovarnogo osetrovodstva Dal'nevostočnogo regiona. [Hybridization as an element of resource-saving technologies of commercial sturgeon in the Far East region.] Pp. 119-120. In: Akvakul'tura osetrovyh ryb: dostiženiâ i perspektivy razvitiâ. Materialy dokladov II Meždunarodnoj naučno-praktičeskoj konferencii. Izdatel'stvo Nova, Astrahan', Russia. [In Russian.]

Turelli M. 1998. The causes of Haldane's rule. Science 282 (5390): 889-891. DOI: 10.1126/science.282.5390.889

Van Eenennaam A.L., Murray J.D., Medrano J.F. 1998. Synaptonemal complex analysis in spermatocytes of white sturgeon, Acipenser transmontanus Richardson (Pisces, Acipenseridae), a fish with a very high chromosome number. Genome 41 (1): 51-61. DOI: 10.1139/g97-101

Van Eenennaam A.L., Murray J.D., Medrano J.F. 1999a. Synaptonemal complex analysis in spermatocytes of white sturgeon (Acipenser transmontanus Richardson). Journal of Applied Ichthyology 15 (4-5): 284. DOI: 10.1111/j.14390426.1999.tb00263.x

Van Eenennaam A.L., Van Eenennaam J.P., Medrano J.F., Doroshov S.I. 1999b. Evidence of female heterogametic genetic sex determination in white sturgeon. Journal of Heredity 90 (1): 231-233. DOI: 10.1093/jhered/90.1.231

Vasil'ev V.P. 1979. Kariotipičeskie različiâ i izoliruûsie mehanizmy v èvolucii ryb. [Karyotypic differences and isolating mechanisms in the evolution of fishes.] Žurnal Obŝej Biologii 40 (4): 623-627. [In Russian.]

Vasil'ev V.P. 1985. Évolûcionnaâ kariologiâ ryb. [Evolutionary karyology of fishes.] Nauka, Moskva. [In Russian.]
Vasil'ev V.P. 1999. Polyploidization by reticular speciation in acipenseriform evolution: a working hypothesis. Journal of Applied Ichthyology 15 (4-5): 29-31. DOI: 10.1111/j.14390426.1999.tb00200.x

Vasil'ev V.P. 2009. Mechanisms of polyploid evolution in fish: Polyploidy in sturgeons. Pp. 97-117. In: Carmona R., Domezain A., García-Gallego J.M., Hernando A., Rodríguez F., Ruiz-Rejón M. (eds.) Biology, conservation and sustainable development of sturgeons. Vol. 29. Fish and Fisheries Series. Springer, Netherlands. DOI: 10.1007/978-1-4020-8437-9_6

Vasil'ev V.P., Sokolov L.I. 1980. Metod izučeniâ kariotipov hrâŝevyh ganoidov (Chondrostei). [The method to study the karyotypes of ganoids (Chondrostei).] Citologiâ 22 (9): 1106-1109. [In Russian.]

Vasil'ev V.P., Vasil'eva E.D., Shedko S.V., Novomodny G.V. 2009. Ploidy levels in the kaluga, Huso dauricus and Sakhalin sturgeon Acipenser mikadoi (Acipenseridae, Pisces). Doklady Biological Sciences 426 (2): 228-231. DOI: $10.1134 / \mathrm{S} 0012496609030119$

Vasil'ev V.P. Vasil'eva E.D., Shedko S.V., Novomodny G.V. 2010. How many times has polyploidization occurred during Acipenserid evolution? New data on the karyotypes of sturgeons (Acipenseridae, Actinopterygii) from the Russian Far East. Journal of Ichthyology 50 (10): 950-959. DOI: 10.1134/S0032945210100048

Vasil'eva E.D., Vasil'ev V.P., Shedko S.V., Novomodny G.V. 2009. The revision of the validity of genus Huso (Acipenseridae) based on recent morphological and genetic data with particular reference to the kaluga $H$. dauricus. Journal of Ichthyology 49 (10): 861-867. DOI: 10.1134/S0032945209100038

Vrijenhoek R.C. 1972. Genetic relationships of unisexualhybrid fishes to their progenitors using lactate dehydrogenase isozymes as gene markers (Poeciliopsis, Poeciliidae). The American Naturalist 106 (952): 754-766.

Received: 25 February 2014

Accepted: 24 September 2014 Published electronically: 31 December 2014 